\title{
Position-Related Somatotype of Elite Female Handball Players
}

\author{
Emilija Petković1, Saša Bubanj ${ }^{1}$, Kristina Marković1, \\ Miodrag Kocić ${ }^{1}$, Daniel Stanković ${ }^{1}$ \\ ${ }^{1}$ University of Niš, Faculty of Sport and Physical Education, Niš, Serbia
}

SUMMARY

Anthropometric characteristics and motor abilities are the most influential factors for the achievement of top sports results. The sample of participants consisted of elite female handball players ( $n=19$, mean age: 27.67 years \pm 6 months), the members of the Serbian senior national team. In this research, their body constitution, i.e. their somatotype was studied. The somatotype was determined according to the methodology of Heath-Carter, using the computer software Somatotype 1.2. The statistical analysis of the results was performed using Statistics v.10. The prevailing somatotype among the female handball players in all positions is the mesomorph somatotype. The obtained results are consistent with the aforementioned characteristics of the mesomorph type conditioned by the specific requirements of the game of handball. Each handball player developed their own musculature and strengthened their skeletal-joint system owing to the contact game and the movements that handball requires.

Key words: female handball players, somatotype, body constitution

Corresponding author:

Emilija Petković

Email: emilija@fsfv.ni.ac.rs 


\section{INTRODUCTION}

Handball is a very dynamic game with fast unpredictable situations, handlings, throws and goalkeeper saves. Team handball is an intermittent sport, characterized by high-intensity explosive movements such as sprints, jumps, throws and very good physical preparation. The game of handball is a contact game with specific types of movement such as moving forwards, backwards, side movements, spin around and feinting, etc. The specific features of handball include ball activities involving arm movement - holding, catching, passing, leading with a ball, and activities such as standing, walking and jogging with a ball $(1,2)$. All this suggests that the physical conditioning of handball players is a complex process and a hard task (3). Success in team handball is determined by a variety of technical and tactical, anthropometric and physical performance characteristics (4). To maximize the potential for success, it is important for such nations to develop talent identification systems, which requires the complete evaluation of elite athletes (5). Performance analyses in sport provide the opportunity to analyze sports movements, ideas for tactical positions and technical mastery, which is especially specific to the positions of the athlete. Although many studies have shown that specific anthropometric characteristics are significantly associated with success in sports (6), various athletic position-related events require different body types for achieving maximum performance. Therefore, understanding anthropometric characteristics and body constitution i.e. the somatotype of top-level athletes has been the subject of different investigations (7-10). Many researchers believe that practicing athletes can develop such functional characteristics that are specifically conducive for their specific sport (11).

Basic and specific motor abilities and morphological characteristics are the most determining factors for achieving maximal success in handball. Playing performance in handball can be determined by analyzing elementary components (12). One of the elementary components are somatic parameters. Differences in anthropometric and physical fitness performance between playing positions are available for male team handball players (13-15). Not as much data have been studied for females $(16,15)$. Somatotyping is one of the most frequently used techniques for body composition analysis. It is usually applied in sport to determine the specificities of male and female team sport players of different age groups (17). In order to predict playing performance and to assign the players to the most appropriate playing positions on the basis of this knowledge, we have to confront this information with functions that are specific for individual playing positions. Certain somatotypes bear certain morphological predispositions for physical activity, manifested differently in somatotype categories (12). Significant correlations between some morphological parameters in handball players and their playing functions was established by Šibila and Pori (18). Vila et al. (19) conducted anthropometric testing of female handball players in the first Spanish league and calculated their somatotype constitution in terms of playing positions. Chiara et al. (20) investigated the anthropometric characteristics and body constitution on a sample of Italian handball players who were grouped according to their success at competitions and the position in the game. The results showed that better players have a significantly lower fat percentage and a higher bone mineral content than the less successful ones. Given the differences between playing positions, a statistically significant difference in growth, weight, body mass index (BMI), several types of skinfold thickness and length, as well as total body mass, muscle mass and fat were compared between players at different playing positions. A post-hoc analysis showed that the wing and goalkeepers differ the most. Vrbik et al. (4) found morphological differences between playing positions in elite male handball players. They analyzed the Croatian junior national handball team and found statistically significant differences between male wings and backs players in longitudinal dimensionality and body volume. Srhoj (21) analyzed the efficacy of anthropomotor types of young female handball players in order to establish the significance of the positional direction and successful plays.

Visible body constitution has an important role not only in determining physical development but also in determining behavior. The somatotype represents a compromise between morphological genotype and phenotype. Somatotypology aims at classifying athletes into several somatotypes (endomorph, ectomorph and mesomorph) for the purpose of selecting athletes for certain sports. Some studies indicate that the endomorph somatotype is not suitable for basketball (22), whereas other studies confirm that the ectomorph type has predispositions for those sports. Ectomorphs are tallish and characterized by relatively longer bones, which makes them suitable for sports which require tall players (high jump, basketball, volleyball, etc.). Many sports games require their athletes to have the mesomorph type of constitution. Athletes are rarely pure endo-, ecto- 
or mesomorph types. They usually have characteristics that are mixtures of two, or rarely, all three types. A mesomorph and endomorph combination of somatotypes is a relatively frequent one among athletes. Selection criteria for determining an individual belonging to constitutional types are very different in practice. From methodological standpoint, several schools are based on the biological distribution of playing positions, among which the most accepted are the French, Italian, German and American school.

The aim of the study was to determine the somatotype of female handball players, the members of the National Team of the Republic of Serbia. The study was conducted to verify whether a specific somatotype is required by a certain playing position in a team. The reason why it is necessary to determine the somatotype based on playing positions were the cumulative statistics from the 2009 World Championships, where the results depended on the tactics of the game. The analyzed number of points achieved from certain playing positions was the fast break throw $(88.23 \%)$, followed by the break-through position shot (75\%). Alexandru et al. (23) showed that the second most efficient position was pivot, at a rate of $15.63 \%$.

\section{MATERIALS AND METHODS}

\section{Participants and procedure}

The sample of participants consisted of elite female handball players ( $n=19$, mean age: 27.67 years \pm 6 months), members of the Serbian senior national team. Based on their playing position, there were left wings (three players), right wings (two players), left backs (three players), right backs (two players), pivots (three players), center backs (three players) and goalkeepers (three players). The Ethics Committee of the University of Niš, Faculty of Sport approved all experimental procedures according to the revised Declaration of Helsinki (24). All of the participants were informed about the purpose and procedures, and potential risks of the study. All of the participants were over the age of 18 and voluntarily participated in the testing.

Constitution, i.e., the somatotype, was determined by the Heath-Carter method (25), which requires anthropometric measurements and included the following 10 variables: body height (in $\mathrm{cm}$ ), body mass (in $\mathrm{kg}$ ), four skinfolds (over triceps, subscapular, supraspinal, and calf; in $\mathrm{mm}$ ), biceps girth (flexed $90^{\circ}$ and tensed; in $\mathrm{cm}$ ), standing calf girth (in $\mathrm{cm}$ ), humerus breadth (in $\mathrm{cm}$ ) and femur breadth (in $\mathrm{cm}$ ). Skinfold sites were landmarked at the triceps, subscapular, biceps, iliac crest, supraspinal, abdominal, front thigh and medial calf on the right side of the participant's body. All sites were then measured using calipers (Holtain, London, UK) with $10 \mathrm{~g} / \mathrm{mm}^{2}$ constant pressure. All of the measurements were taken by the same authors in the optimal climatic conditions, with the participants in their underwear, and according to the methods proposed by the International Biological Programme (15). Body mass was measured with a digital scale, Omron BF511 (Kyoto, Japan). BMI was determined according to the National Heart, Lung and Blood Institute (26). Each measure was taken two or three times (27) by the same Level 1 accredited investigator. Technical error of top-elite female handball players measurement was $<3 \%$ for skinfolds, and $<1 \%$ for breadths and girths, which were deemed acceptable by ISAK (International Society for Advancement of the Kinanthropometry) standards (28, 29). Somatotypes were determined using the methods previously described by Carter and Heath (25).

\section{Statistical analysis}

The somatotype was determined according to the methodology of Heath-Carter (25), using the computer program Somatotype 1.2. The results were statistically analyzed using Statistics v.10 (SPSS Inc., Chicago, IL) and presented descriptively in tables and figure.

\section{RESULTS}

The obtained data are presented in tables and graphs (by somatoplots). The sample of 19 elite female handball players showed that the mean somatotype was: 3.31-5.73-2.66 (values for endomorphy, mesomorphy and ectomorphy, respectively; (Table 1). Their average somatotype classifies them as balanced mesomorphs. The high level of the mesomorph component is in accordance with the fact that elite female handball players are required to have muscle strength which is indicated by a mesomorph or some other component of a somatotype.

The Table 1 shows mean values of body height $175.42 \pm 6.94 \mathrm{~cm}$, body mass $70.00 \pm 9.78 \mathrm{~kg}$ and BMI 22 . $66 \pm 2.01 \%$, which are within the normal range of values and typical for elite female handball players.

Urban et al. (30) at the $19^{\text {th }}$ women's European Championship calculated the somatotype of the players, where the moderate mesomorph constitution was the prevailing type of constitution. Their findings for the handball teams ranking from the $1^{\text {st }}$ to $8^{\text {th }}$ place shared 
Table 1. Descriptive statistics for the somatotype of the Serbian Senior Women's Handball Team

\begin{tabular}{lccccccc}
\hline \hline & $\mathbf{N}$ & Mean & Min & Max & St. Dev & Skew & Kurt \\
\cline { 2 - 8 } BH & 19 & 175.42 & 165.00 & 192.00 & 6.93 & 0.46 & 0.10 \\
BM & 19 & 70.00 & 55.00 & 88.00 & 9.78 & 0.10 & -0.98 \\
BMI & 19 & 22.66 & 19.88 & 26.86 & 2.01 & 0.45 & -0.32 \\
Endo & 19 & 3.31 & 2.00 & 5.30 & 0.87 & 0.36 & -0.09 \\
Meso & 19 & 5.73 & 3.30 & 8.20 & 1.29 & -0.19 & -0.24 \\
Ecto & 19 & 2.66 & 1.20 & 4.20 & 0.84 & -0.11 & -0.70 \\
\hline \hline
\end{tabular}

Legend: N-number of participants; Mean- arithmetic mean; Min-minimum and Max-maximum value; St. Devstandard deviation; Skew- skewness; Kurt-kurtosis; BH - body height; BM - body mass; BMI - body mass index.

proportionally higher values of endomorphy (2.3-2.5) and mesomorphy (4.3 to 4.5), but lower values of ectomorphy (1.9-2.0), indicating a relatively low linear body build with higher values of body mass and subcutaneous fat, a larger skeleton and well-developed muscles. On the other hand, teams ranking from $9^{\text {th }}$ to $16^{\text {th }}$ place show a relatively lower value of endomorphy (2.0-2.2), a lower value of mesomorphy (3.6-4.1), but increased ectomorphy (from 2.2 to 2.6), indicating the linear build of these team players with long segments of some body parts, lower values of body mass and subcutaneous adipose tissue and relatively lower volume of muscles.

Figure 1 (somatogram) shows the individual cases, 13 of which belong to the mesomorph zone, two of which are close to the ectomorph zone; one was in the ectomorph zone, one was in the endomorph zone, while two are from the mesomorph zone. The somatogram shows a pretty high mesomorph component in all individual cases.

The results have shown that the female handball players of the National Team of the Republic of Serbia are characterized by high values of the mesomorph component, which is in some cases combined with the ectomorph and more rarely with the endomorph one. It can be concluded that the obtained results were the outcome of the study which included testing a larger number of back players than line players.

From the aspect of somatic predispositions, the player's somatotype itself determines the efficiency of the fulfillment of position-specific playing functions: goalkeeper - covering the goal area: arm span and total length of the frontal body part; pivot - efficiency in physical contact: body mass, transversal and body volume dimensions; center back and back - 9 meter shooting: body height, arm span and palm breadth; wing - speed and acceleration: low body mass and percent subcutaneous fat and well-developed musculature (12).

Table 2 shows the average somatotypes of elite female handball players of the Republic of Serbia senior national team (left and right wing, left and right back, center back, pivot and goalkeeper). Serbian female handball left wings are ecto-mesomorphs, right wings are endo- mesomorphs, left, right and center backs are central somatotypes, pivots are endomorph - mesomorphs, goalkeepers are of the mesomorph-endomorph type. The mesomorph component values range from 4.6 in goalkeepers, to 7.5 in pivot, while in other positions the values range from 5.1 to 5.9 ; a very high mesomorph component which features muscular strength is typical for elite female handball players. In terms of the playing positions, research from Vila et al. (19) had similar results as Serbian female handball national team, concluded that the center backs, backs and wings mostly belonged to the mesomorph constitution type, while pivot players and goalkeepers belonged to the endomorph type. Srhoj et al. (31) discovered that back players' and goalkeepers' body and skeleton dimensions are predominantly increased. Wing players and pivot players are less longitudinally dimensioned, whereas pivot players have a larger amounts of fat. Moss et al. (32) examined the somatotype profile of team handball 


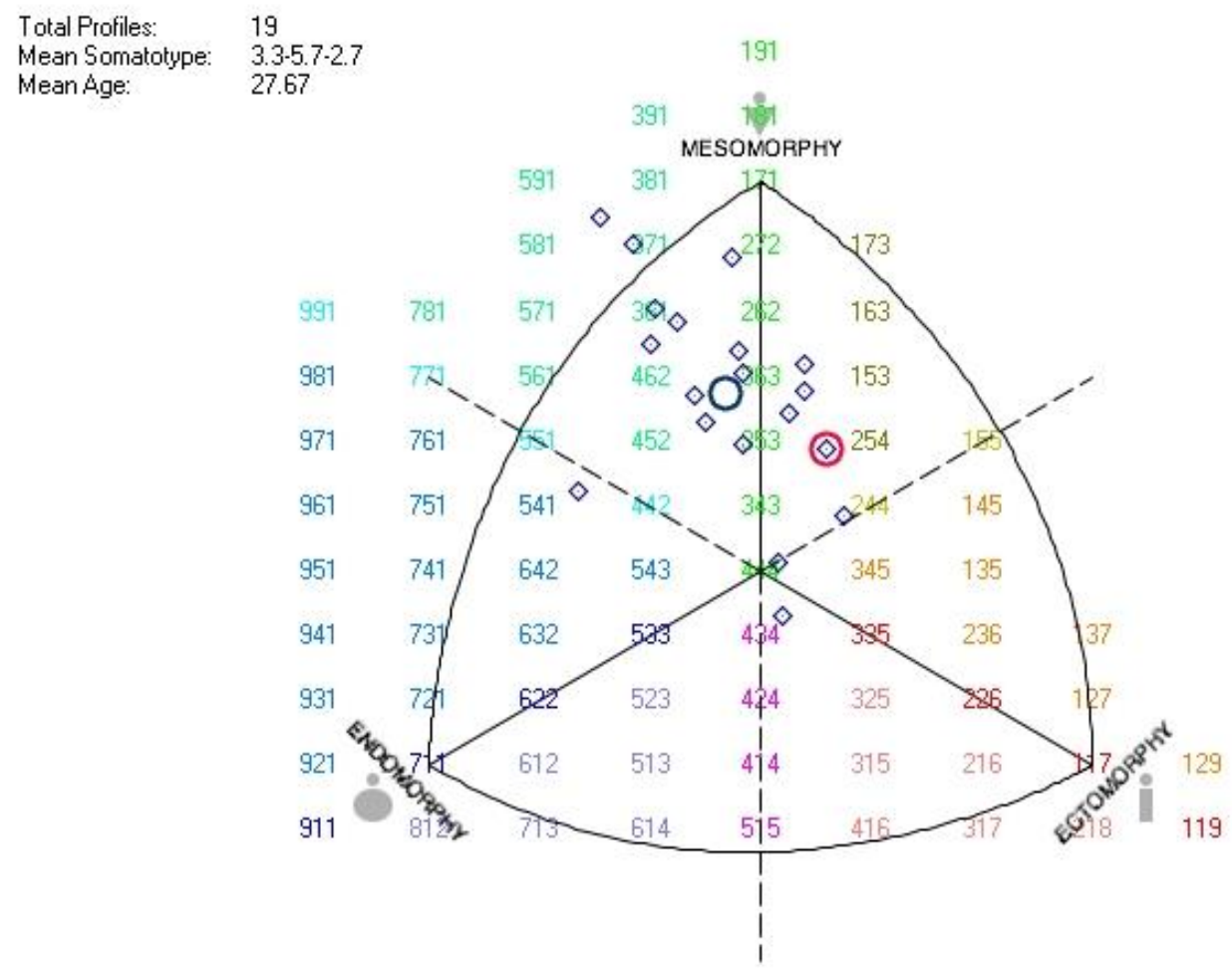

Figure 1. Somatogram of the Serbian Senior Women's Handball Team

players in elite, top-elite and non-elite players.

Elite (3.8-3.3-2.6) players were mesomorphicendomorph, which was similarly to the result of the mean values of Serbian National Team (3.3-5.7-2.7) mesomorph component. Our results are similar and show that mesomorph type with the endomorph appears in wing players (min. value 2.2-4.2-2.4; max. value 3.1-5.3-3.1), whereas the mesomorph type combined with the ectomorph one appears in back players ( $\mathrm{min}$. value 3.3-5.1-2.8; max. value 3.4-5.8-3.2). Pivot players and goalkeepers belonged to the endomorph type (min. value 3.3-4.6-1.4; max. value 4.2-7.5-2.8).

Table 2 shows that the lowest values of $\mathrm{BH}$ (167.00 \pm 2.00$)$, BM $(57.33 \pm 3.21)$ and BMI $(20.55 \pm 0.71)$ are evident in left wings. The highest $\mathrm{BH}(184.67 \pm 6.43)$ is found in left backs, the highest BM $(81.00 \pm 8.19)$ and BMI $(25.81 \pm 1.28)$ are found in pivots who are of the endomorph-mesomorph type. Milanese et al. (33) examined the anthropometric status of 26 competitive level female handball players of the Italian League (aged 26.4 \pm 5.77 months), which is similar to the age of our sample of female handball participants (age: $27.67 \pm 6$ months); with less body mass $(67.0 \pm 7.91 \mathrm{~kg})$ than the Serbian players $(70,00 \pm 9,78 \mathrm{~kg})$; lower stature $(169.2 \pm 6.04 \mathrm{~cm})$ than the Serbian players $(175.42 \pm 6.94 \mathrm{~cm})$; and higher percentage BMI $(23.4 \pm 5.33 \%)$ than the Serbian players $(22.66 \pm 2.01 \%)$. Both teams of female handball players are within the normal range of values and typical for elite female handball players.

Differences between goalkeepers and wings were found in the measures of body height, body mass and abdomen skinfold. Significant differences between wing attack players and left back players were found in the variables of body height $( \pm 17 \mathrm{~cm})$, body mass $( \pm 20 \mathrm{~kg})$. Differences between back court players, pivots and goalkeepers were not found in the space of morphological characteristics. It is assumed that this is due to the modern concept of handball, where players' versatility in the sense of playing different positions is a necessity. 
Table 2. The average somatotype of the Serbian Senior Women's Handball Team regarding the playing positions in a team

\begin{tabular}{|c|c|c|c|c|c|c|}
\hline Pos. & $\mathbf{N}$ & Somatotype & Average somatotype & BH & BM & BMI \\
\hline LW & 3 & $\begin{array}{l}2.2-4.7-3.4 \\
2.4-6-3.2 \\
2-5.2-2.8\end{array}$ & $\begin{array}{c}2.2-5.3-3.1 \\
( \pm 0.20-0.66-0.31) \\
\text { Ectomorph - mesomorph }\end{array}$ & $\begin{array}{c}167.00 \pm \\
2.00\end{array}$ & $\begin{array}{c}57.33 \pm \\
3.21\end{array}$ & $\begin{array}{c}20.55 \pm \\
0.71\end{array}$ \\
\hline RW & 2 & $\begin{array}{l}3.6-6.7-1.7 \\
2.7-5.4-3.2\end{array}$ & $\begin{array}{c}\text { 3.1 - } 4.1-2.4 \\
\qquad \pm 0.64-1.84-2.45) \\
\text { Endomorph - mesomorph }\end{array}$ & $\begin{array}{c}167.50 \pm \\
0.71\end{array}$ & $\begin{array}{c}62.00 \pm \\
5.66\end{array}$ & $\begin{array}{c}22.10 \pm \\
2.20\end{array}$ \\
\hline LB & 3 & $\begin{array}{l}3.6-5.4-3.2 \\
3.1-6.3-2.7 \\
3.3-3.6-3.6\end{array}$ & $\begin{array}{c}3.3-5.1-3.2 \\
( \pm 0.26-1.37-0.46) \\
\text { Balanced mesomorph }\end{array}$ & $\begin{array}{c}184.67 \pm \\
6.43\end{array}$ & $\begin{array}{c}77.00 \pm \\
5.29\end{array}$ & $\begin{array}{c}22.45 \pm \\
0.61\end{array}$ \\
\hline $\mathbf{R B}$ & 2 & $\begin{array}{c}4-5.8-3 \\
2.9-5.8-2.6\end{array}$ & $\begin{array}{c}3.4-5.8-2.8 \\
( \pm 0.78-0.00-0.28) \\
\\
\text { Balanced mesomorph }\end{array}$ & $\begin{array}{c}177.00 \pm \\
8.49\end{array}$ & $\begin{array}{c}70.50 \pm \\
7.78\end{array}$ & $\begin{array}{c}22.46 \pm \\
0.33\end{array}$ \\
\hline CB & 3 & \begin{tabular}{|l|}
$4.5-7-2.5$ \\
$2.3-3.9-3.8$ \\
$3.6-6.7-2.1$
\end{tabular} & $\begin{array}{c}3.5-5.9-2.8 \\
( \pm 1.11-1.71-2.80) \\
\text { Balanced mesomorph }\end{array}$ & $\begin{array}{c}176.00 \pm \\
2.65\end{array}$ & $\begin{array}{c}69.67 \pm \\
8.39\end{array}$ & $\begin{array}{c}22.59 \pm \\
1.86\end{array}$ \\
\hline $\mathbf{P}$ & 3 & $\begin{array}{l}3.5-7.4-1.2 \\
4.2-8.2-1.3 \\
2.2-6.8-1.7\end{array}$ & $\begin{array}{c}\quad 3.3-7.5-1.4 \\
\qquad \pm 1.01-0.70-0.26) \\
\text { Endomorph - mesomorph }\end{array}$ & $\begin{array}{c}177.00 \pm \\
4.58\end{array}$ & $\begin{array}{c}81.00 \pm \\
8.19\end{array}$ & $\begin{array}{c}25.81 \pm \\
1.28\end{array}$ \\
\hline G & 3 & $\begin{array}{c}3.6-5.7-2.4 \\
3.8-3.3-4.2 \\
5.3-4.9-2\end{array}$ & $\begin{array}{c}4.2-4.6-2.8 \\
( \pm 0.93-1.22-1.17) \\
\text { Mesomorph - endomorph }\end{array}$ & $\begin{array}{c}176.67 \pm \\
4.61\end{array}$ & $\begin{array}{c}70.00 \pm \\
8.89\end{array}$ & $\begin{array}{c}22.41 \pm \\
2.41\end{array}$ \\
\hline
\end{tabular}

Legend: Pos. - position, $\mathrm{N}$ - number of participant, LW - left wing; RW - right wing; LB - left back; RB - right back; $\mathrm{CB}$ - center back; P - pivot; $\mathrm{G}$ - goalkeeper; $\mathrm{BH}$ - body height; $\mathrm{BM}$ - body mass; $\mathrm{BMI}$ - body mass index.

\section{DISCUSSION}

The results obtained by the analysis of the selected sample of participants showed that the mesomorph type is the prevailing one, which was expected, given the characteristics of a handball game, as well as the characteristics featuring the mesomorph type. However, there are cases of a mesomorph type com- bined with an ectomorph and less with endomorph one, since the conditions of the game of handball, especially with tall defensive players, require tall offensive back players who are physically predisposed to respond better to the situational stimuli. Since this study encompassed a larger number of offensive back players than line players, such results were acceptable.

The aim of this study was to determine the so- 
matotype of elite Serbian female handball players individually and in relation to their playing position on the team, in order to verify whether the position requires a specific somatotype, which has been achieved. It can be concluded that the mesomorph type with the endomorph one is present in wing players, whereas the mesomorph type combined with the ectomorph appears in back players. The average somatotype classifies Serbian senior female handball players in all positions as balanced mesomorphs, like the analyzed mean somatotype of the U17 female handball players, classified as balanced mesomorph: 2.36 - 4.17 - 2.22, according to Urban (34). The mean somatotypes of nine national teams: Russia, Denmark, Hungary, France, Romania, Croatia, Czech Republic, Portugal and Austria were categorized as balanced mesomorphs. The mean somatotypes of four national teams of the Netherlands, Spain, Poland and Slovakia (U17) were categorized as endomorphic-mesomorphs. The average somatotypes of players on the Sweden and German national teams were categorized as ectomorphic-mesomorphs (35). The obtained results are consistent with the mentioned characteristics of a mesomorph type conditioned by specific requirements of the game of handball. Each handball player developed their own musculature and strengthened the skeletal joint system, thanks to the contact game and the movements that handball requires.

Previous studies $(12,30,34,35)$ have shown that anthropometry has an important role as diagnostic procedure in the selection of handball players according to playing positions.

\section{CONCLUSION}

Morphological characteristics are good predictors of players' success, which is evident in longitudinal dimensionality, the range and size of a hand and reduced role of the subcutaneous adipose tissue. A significant difference is noted between playing positions of back players, goalkeepers and pivots, featuring the prominence of longitudinality and voluminosity, and positions featuring low levels of longitudinal dimensionality as the fact that the wing players have being the shortest ones.

\section{Limitations and strengths of the study}

This study does not take into consideration other abilities that influence performance in sports (such as motor abilities, psychological state, functional abilities, etc.). Therefore, we recommended the multidisciplinary approach and analysis of body constitution and somatotype of the national team female handball players participating in the continental and world championships in all categories. The general somatotype model of top female Serbian handball players should be determined. To the best of our knowledge, this is the first study that has reported the somatotype of elite Serbian female handball players individually and in relation to their playing position in a team. These findings are not the final results and we are aware that the somatotype and body constitution of elite female handball players must follow the modern trend of development in the world of the game of handball. Within the National project No 179019, we were provided with the opportunity for the first time in Serbia to determine the somatotype of top female handball athletes, and we believe that these findings contributed to the knowledge of the field. Further study might improve our understanding of the characteristics needed to achieve excellence so that the selection processes can be modelled accordingly, and highlight that youth elite players differ only in a few characteristics.

\section{Practical applications}

Apart from helping coaches in the selection of handball players, such information would facilitate their further work in the training process and thus enable top results. Selecting a player in a position in the game can greatly assist the coach to use their somatotypes to reach the desired position in the team. Therefore, professionals working in handball should be informed of these findings.

\section{Acknowledgement}

This research is part of the project of the Ministry of Science and Technological Development of the Republic of Serbia, "Biomechanical Efficiency of the Top Serbian Athletes" (No 179019). The authors would like to thank the Handball Federation of Serbia, who made this study possible.

\section{Conflict of interest statement}

The authors declare that they have no conflict of interest with reference to this paper. 


\section{References}

1. Michalsik LB, Aagaard P, Madsen K. Locomotion characteristics and match-induced impairments in physical performance in male elite team handball players. Int J Sports Med 2013a; 34: 590-9.

https://doi.org/10.1055/s-0032-1329989

2. Michalsik LB, Madsen K, Aagaard P. Match performance and physiological capacity of female elite team handball players. Int J Sports Med 2014a; 35: 595607.

\section{https://doi.org/10.1055/s-0033-1358713}

3. Pavlović, Lj, Bojić, I, Stojiljković, N, et al. Seasonal changes in selected physical and physiological variables in male handball players. Acta Fac Med Naiss 2018; 35: 226-35.

4. Vrbik I, Čižmek A, Gruić I. Morphological characteristics between playing positions in elite handball players. Croat Sports Med J 2011; 26: 94-9.

5. Carter JEL, Ackland TR, Kerr DA, et al. Somatotype and size of elite female basketball players. J Sports Sci 2005; 23: 1057-63.

https://doi.org/10.1080/02640410400023233

6. Malina RM, Bouchard C, Bar-Or O. Growth, maturation, and physical activity: Human Kinetics; 2004.

7. Massidda M, Toselli S, Brasili P, et al. Somatotype of elite Italian gymnasts. Coll Antropol 2013; 37 Suppl. 3: 853.

8. Popović S, Bjelica D, Jaksić D, et al. Comparative study of anthropometric measurement and body composition between elite soccer and volleyball players. Int J Morph 2014; 32: 267-74.

\section{https://doi.org/10.4067/S0717-95022014000100044}

9. Stanković D, Pavlović D, Petković E, Raković A, Puletić M. The somatotypes and body composition of elite track and field athletes and swimmers. Int J Sports Sci 2018; 8 : 67-77.
10. Zapartidis I, Vareltzis I, Gouvali M, et al. Physical fitness and anthropometric characteristics in different levels of young team handball players. Open Sports Sci J 2009; 2: 22-8.

https://doi.org/10.2174/1875399X00902010022

11. Singh S, Singh K, Singh M. Anthropometric measurements, body composition and somatotyping of high jumpers. Braz J Biomotricity 2010; 4: 266-71.

12. Vila H, Manchado C, Abraldes A, et al. Anthropometric profile in female elite handball players by playing positions. In: Taborsky, F (Ed), EHF Scientific Conference 2011, Science and Expertise in Handball (Scientific and practical approaches), Wien; 2011: 219-22.

13. Matthys SPJ, Vaeyens R, Vandendriessche J, et al. A multidisciplinary identification model for youth handball. Eur J Sport Sci 2011; 11: 355-63.

https://doi.org/10.1080/17461391.2010.523850

14. Mohamed H, Vaeyens R, Matthys $\mathrm{S}$, et al. Anthropometric and performance measures for the development of a talent detection and identification model in youth handball. J Sports Sci 2009; 27: 257-6.

https://doi.org/10.1080/02640410802482417

15. Weiner JS, Lourie JA. Human Biology, A guide to Field methods. International Biological Programme. Edinburgh: Blackwell Scientific Publications; 1969.

16. Granados C, Izquierdo M, Ibañez J, et al. Differences in physical fitness and throwing velocity among elite and amateur female handball players. Int J Sports Med 2007; 28: 860-7.

https://doi.org/10.1055/s-2007-964989

17. Bayios IA, Bergeles NK, Apostolidis NG, et al. Anthropometric, body composition and somatotype differences of Greek elite female basketball, volleyball and handball players. J Sports Med Phys Fitness 2006; 46: $271-80$. 
18. Šibila M, Pori P. Position-related differences in selected morphological body characteristics of top-level handball players. Coll Antropol 2009; 33: 1079-86.

19. Vila H, Manchado $\mathrm{C}$, Rodriguez $\mathrm{N}$, et al. Anthropometric profile, vertical jump, and throwing velocity in elite female handball players by playing positions. J Strength Cond Res 2012; 26: 2146-55.

https://doi.org/10.1519/ISC.0b013e31823b0a46

20. Chiara M, Piscitelli F, Chiara L, et al. Anthropometry and body composition of female handball players according to competitive level or the playing position. J Sports Sci 2011; 29 : 1301-19.

https://doi.org/10.1080/02640414.2011.591419

21. Srhoj V. Situational efficacy of anthropomotor types of young female handball players. Coll Antropol 2002; 26 Suppl. 1: 211-8.

22. Pehar M, Sekulić D, Sisić N, et al. Evaluation of different jumping tests in defining position-specific and performance-level differences in high level basketball players. Biol Sport 2017; 34: 263-72.

https://doi.org/10.5114/biolsport.2017.67122

23. Alexandru E, Alexandru A. The quantitative model of the finalizations in men's competitive handball and their efficiency. J Phys Edu Sport 2009; 24 (3) : 1-6.

24. World Medical Association. World Medical Association Declaration of Helsinki Ethical Principles for Medical Research Involving Human Subjects. JAMA 2013;310:2191-94

https://doi.org/10.1001/jama.2013.281053

25. Carter JEL, Heath BH. Somatotyping. Development and applications. New York: Cambridge University Press; 1990.

26. Stewart $\mathrm{AD}$, Marfell-Jones $\mathrm{M}$, Olds $\mathrm{T}$, et al. International standards for anthropometric assessment. International Society for the Advancement of Kinanthropometry. 2011.

27. Ballew, C., Khan, L. K., Kaufmann, R., Mokdad, A., Miller, D. T., \& Gunter, E. W. Blood lead concentration and children's anthropometric dimensions in the Third National Health and Nutrition Examination Survey (NHANES III), 1988-1994. J Pediatrics 1999; 134, 623-30.

28. Ross WD, Marfell-Jones MJ. Kinanthropometry. Physiological testing of elite athlete. London. Human Kinetics. 1991: 223-308.

29. Carter JEL. The Heath-Carter anthropometric somatotype: Instruction manual. 2002; Available at: http://www.somatotype. org/Heath-CarterManual.pdf

30. Urban F, Kandráč R, Táborský F. Anthropometric profiles and somatotypes of the national teams at the 2011 women's 17 European Handball Championship 2011. In EHF Web Periodical. Available at: http://cms.eurohandball.com/PortalData/1/Resources/4 activities/3 pdf act/European Championship W17 CZ E - Anthropometric Profiles and Somatotypes.pdf

31. Srhoj V, Marinović M, Rogulj, N.. Position specific morphological characteristics of top-level male handball players. Coll Antropol 2002; 26 Suppl 1: 219-27.

32. Moss SM, Mcwhannell N, Michalsik LB, et al. Anthropometric and physical performance characteristics of top-elite, elite and non-elite youth female team handball players. J Sports Sci 2015; 33: 178089.

\section{https://doi.org/10.1080/02640414.2015.1012099}

33. Milanese C, Piscitelli F, Lampis C, et al. Effect of a competitive season on anthropometry and threecompartment body composition in female handball players. Biol Sport 2012; 29: 199-204

https://doi.org/10.5604/20831862.1003443

34. Urban F. Somatotypes of handball players. Diploma Thesis. Prešov: FŠ PU. 2010: 87.

35. Urban F, Kandráč R, Táborský F. Position-related categorization of somatotypes. In: Top level handball players. EHF Web Periodical, 2014. Available at: https://www.researchgate.net/profile/Frantisek Urban/p ublication/222108359 Position-

Related Categorization Of Somatotypes In Top Level Handball Players/links/02faf4f7d90994f5f2000000.pdf 


\title{
Somatotip u odnosu na igračku poziciju vrhunskih rukometašica
}

\author{
Emilija Petković ${ }^{1}$, Saša Bubanj ${ }^{1}$, Kristina Marković ${ }^{1}$, \\ Miodrag Kocić1, Daniel Stanković ${ }^{1}$ \\ ${ }^{1}$ Univerzitet u Nišu, Fakultet sporta i fizičkog vaspitanja, Nǐ̌, Srbija
}

\section{SAŽETAK}

Antropometrijske karakteristike i motoričke sposobnosti su faktori koji najviše utiču na ostvarenje vrhunskih sportskih rezultata. Uzorak ispitanika sačinjavale su vrhunske rukometašice $(n=19$, prosečne starosti: 27,67 godina \pm 6 meseci), pripadnice nacionalnog tima Srbije. $U$ ovom istraživanju proučavali smo njihovu telesnu konstituciju, tj. njihov somatotip. Somatotip je određen prema metodologiji Heath-Carter, upotrebom softvera Somatotipe 1.2. Statistička analiza rezultata sprovedena je uz pomoć softvera Statistics v.10. Preovladavajući somatotip među rukometašicama na svim pozicijama je mezomorfni somatotip. Dobijeni rezultati u skladu su sa navedenim karakteristikama mezomorfnog tipa uslovljenim specifičnim zahtevima rukometa. Svaka rukometašica razvila je sopstvenu muskulaturu i ojačala svoj skeletni sistem zahvaljujući kontaktnoj igri i pokretima koje rukometna igra zahteva.

Ključne reči: rukometašice, somatotip, telesna konstitucija 